\section{Detection of Coliforms in table eggs}

Sama'a M. Mo'ataz ${ }^{1}$, Nagah M. saad ${ }^{2}$ and Tawfik A. ELBassiony $^{3}$

${ }^{1}$ Department of food hygiene, Faculty of Veterinary Medicine, Assiut University,dr_samaa89@yahoo.com.

${ }^{2}$ Department of food hygiene, Faculty of Veterinary Medicine, Assiut University, bosbosadel_78@yahoo.com.

${ }^{3}$ Department of food hygiene, Faculty of Veterinary Medicine, Assiut University, elbassiony@yahoo.com.
* Corresponding Author

Sama'a M. Mo'ataz, Department of food hygiene, Faculty of Veterinary Medicine, Assiut University, 71515, Assiut, Egypt. dr_samaa89@yahoo.com

Submitted 8/16/2021

Accepted 9/5/2021

\begin{abstract}
The objective of this study was to determine the presence of coliforms, fecal coliform and Escherichia coli in both baladi and farm table eggs in both shells and contents. A total of 100 farms and baladi eggs samples (50 samples of each) were randomly collected from poultry farms, markets, supermarkets, and groceries in Assiut governorate. Eggs were microbiologically examined, and isolates were identified by biochemical and (PCR). The obtained results revealed that coliform and fecal coliform incidences were $62,56,54$ and $32 \%$ for the farm hens' eggshell, egg content, baladi hens' eggshell and egg content, respectively. The biochemical identification of revealed 16 isolates of E. coli and these results were complementary with the molecular identification. E.coli incidence was 6, 8, 12 and $6 \%$ for the farm hens' eggshell, egg content, baladi hens' eggshell and egg content, respectively. The public health significance and hygienic control measures were discussed in this study..
\end{abstract}

Keywords: Baladi hen , Coliform, E-Coli, Egg

\section{Introduction}

Table eggs are the best and easy source of food, containing quality protein, essential amino acids, essential vitamins and minerals needed for good health (MAFF, 2009). Freshly laid eggs are generally devoid of organisms. However, following exposure to environmental conditions (for example, soil, dust and dirty nesting materials), eggs become contaminated with different types of microorganisms (Ellen et al., 2000)Eggs are liable to contamination either before laying (congenitally) or after laying when the microorganisms reach the egg contents through penetration the shell and cause low egg quality, low shelf life and safety inducing public health hazards (Board and Fuller, 1994), in addition, fecal matter, improper washing, using of contaminated water and bad handling are the common sources of contamination. Coliforms count is the traditional indicator of possible fecal contamination, microbial quality, wholesomeness and reflects the hygienic standards adopted in the food operation. The bacteria most frequently isolated from eggs are Gram-negative bacteria such as E. coli, Enterobacter, and Klebsiella spp. (Musgrove et al., 2008).E. coli is a normal inhabitant of the intestinal tract of both man and animals and can penetrate the shell contaminating the egg contents (Mayes and Takeballi, 1983). E. coli is a Gram-negative, facultative anaerobe, rod-shaped bacterium, and the normal habitat in the lower intestine of warm-blooded organisms (Singleton, 1999). Most E. coli strains are harmless, but some pathogenic strains can cause food poisoning as severe abdominal cramps, diarrhea in addition to urinary tract infections, and neonatal meningitis. In rarer cases, virulent strains have a major role in bowel necrosis (Todar, 2007).Considering the above information, this study was conducted to detect Coliforms, fecal coliform and E. coli in farm and baladi hens' eggs.

\section{Materials and Methods}

A total of 500 random eggs, representing 100 samples (50 from Poultry farms hens' and 50 from Baladi hens'). ( Each sample was represented by 5 eggs) were collected from different poultry farms, groceries, different markets and supermarkets located in Assiut 
governorate, Egypt. Eggs samples were collected in clean and sterile bags and transferred as soon as possible to the laboratory for microbiological examination:

A. Preparation of eggs samples for microbiological examination:

1-Eggshell was prepared by surface rinse method according to (Moats, 1979).

2-Egg content was evacuated for microbiological examination according to Speck (1976).

\section{B. Preparation of serial dilutions (APHA, 1992):}

Ten-fold serial dilutions up to $10^{\wedge}(-3)$ were aseptically prepared from the rinse solutions. As well as, from the homogenous egg contents using sterile saline.

\section{Microbiological examination of the prepared eggshell solution as well as egg content by the flowing:}

Total coliforms, fecal coliforms, and E. coli count by MPN technique according to (AOAC,1980)

D. Biochemical identification (MacFaddin, 2000)

Indole tests, Methyl Red test, Voges-Proskauer test and Citrate utilization test (IMViC test).

E. Molecular identification of Escherichia coli isolates using conventional polymerase chain reaction $(\mathrm{PCR})$ :

This part has been done in Animal Health Research Institute, Dokki, Giza, Egypt.

\section{1) DNA extraction}

Positive biochemical isolates were performed to DNA extraction using boiling method (Queipo-Ortun et al., 2008)

\section{2) PCR: (Hu et al., 2011)}

\section{I.Oligonucleotide primers:}

\section{Source: Midland Certified Reagent Company_} oilgos (USA).

They have specific sequence and amplify a specific product as shown in the following table

\begin{tabular}{|c|c|c|c|}
\hline 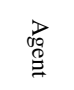 & $\begin{array}{l}\text { बे } \\
\stackrel{\emptyset}{\sigma}\end{array}$ & Sequence & 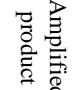 \\
\hline \multirow{2}{*}{ E. coli } & 2 & F: CGATTCTGGAAATGGCAAAAG & \multirow{2}{*}{$720 \mathrm{bp}$} \\
\hline & & R: CGTGATCAGCGGTGACTATGAC & \\
\hline
\end{tabular}

\section{II.PCR amplification}

\begin{tabular}{|c|c|}
\hline Component & Volume/reaction \\
\hline $\begin{array}{c}\text { Emerald Amp GT PCR master mix } \\
\text { (2x premix) }\end{array}$ & $12.5 \mu \mathrm{l}$ \\
\hline PCR grade water & $5.5 \mu \mathrm{l}$ \\
\hline Forward primer(20 pmol) & $1 \mu \mathrm{l}$ \\
\hline Reverse primer (20 pmol) & $1 \mu \mathrm{l}$ \\
\hline Template DNA & $5 \mu \mathrm{l}$ \\
\hline Total & $25 \mu \mathrm{l}$ \\
\hline
\end{tabular}

III. Cycling conditions of the primers during CPCR

\begin{tabular}{|c|c|c|c|c|c|c|c|}
\hline 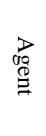 & $\begin{array}{l}\stackrel{Q}{0} \\
\stackrel{\vec{\sigma}}{\vec{\sigma}}\end{array}$ & 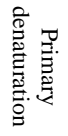 & 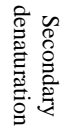 & 总 & 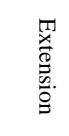 & $\begin{array}{l}Z \\
0 \\
0 \\
0 \\
\vdots \\
o \\
0 \\
0\end{array}$ & 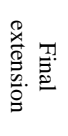 \\
\hline $\begin{array}{l}\pi \\
\vdots \\
\vdots\end{array}$ & $\frac{0}{2}$ & 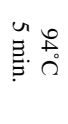 & 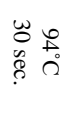 & 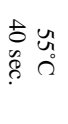 & 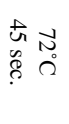 & $w_{u}$ & $\begin{array}{l}\overrightarrow{0} \vec{N} \\
\stackrel{\Omega}{0} \\
E\end{array}$ \\
\hline
\end{tabular}

\section{DNA Molecular weight marker}

The ladder (Fermentas $®$ ) was mixed gently by pipetting up and down. $6 \mu$ of the required ladder were directly loaded.

\section{Agarose gel electrophoreses (Sambrook et al., 1989) with modification}

Electrophoresis grade agarose $(1.5 \mathrm{~g})$ was prepared in $100 \mathrm{ml} \mathrm{TBE}$ buffer in a sterile flask, it was heated in the microwave to dissolve all granules with agitation, and allowed to cool at $70^{\circ} \mathrm{C}$, then $0.5 \mu \mathrm{g} / \mathrm{ml}$ ethidium bromide was added and mixed thoroughly.

The warm agarose was poured directly into the gel casting apparatus with the desired comb in apposition and left at room temperature for polymerization. The comb was then removed, and the electrophoresis tank was filled with TBE buffer. $20 \mu$ of each uniplex PCR product, negative control and positive control were loaded to the gel. The power supply was $1-5$ volts $/ \mathrm{cm}$ of the tank length. The run was stopped after about 30 min and the gel was transferred to UV cabinet.

The gel was photographed by a gel documentation system and the data was analyzed through computer software. 


\section{Results}

Table 1: Incidence of coliforms and fecal coliforms recovered from the examined samples using MPN/ml.

\begin{tabular}{|c|c|c|c|c|}
\hline \multirow{2}{*}{ Egg samples } & \multicolumn{4}{|c|}{ Positive samples } \\
\cline { 2 - 5 } & \multicolumn{2}{|c|}{ Coliforms } & \multicolumn{2}{c|}{ Fecal coliforms } \\
\hline $\begin{array}{c}\text { Farm hens' egg } \\
\text { shells }\end{array}$ & 31 & 62 & 31 & 62 \\
\hline $\begin{array}{c}\text { Farm hens' egg } \\
\text { contents }\end{array}$ & 28 & 56 & 28 & 56 \\
\hline $\begin{array}{c}\text { Baladi hens' egg } \\
\text { shells }\end{array}$ & 27 & 54 & 27 & 54 \\
\hline $\begin{array}{c}\text { Baladi hens' egg } \\
\text { contents }\end{array}$ & 16 & 32 & 16 & 32 \\
\hline
\end{tabular}

Table 2: Frequency distribution of the examined samples of shell and content of based on their Coliforms and Fecal Coliform count (MPN/ml).

\begin{tabular}{|c|c|c|c|c|c|c|c|c|}
\hline \multirow{3}{*}{ Count } & \multicolumn{8}{|c|}{$\begin{array}{l}\text { Farms eggs samples (No./50) } \\
\text { Baladi eggs samples (No./50) }\end{array}$} \\
\hline & \multicolumn{2}{|c|}{ Shells } & \multicolumn{2}{|c|}{ Contents } & \multicolumn{2}{|c|}{ Shells } & \multicolumn{2}{|c|}{ Contents } \\
\hline & No. & $\%$ & No. & $\%$ & No. & $\%$ & No. & $\%$ \\
\hline$<3^{*}$ & 19 & 38 & 22 & 44 & 23 & 46 & 34 & 68 \\
\hline $3-<10$ & 11 & 22 & 9 & 18 & 9 & 18 & 3 & 6 \\
\hline $10-<\mathbf{1 0}^{\mathbf{2}}$ & 10 & 20 & 7 & 14 & 7 & 14 & 1 & 2 \\
\hline $\begin{array}{l}10^{2}- \\
<10^{3}\end{array}$ & 4 & 8 & 8 & 16 & 2 & 4 & 8 & 16 \\
\hline $\begin{array}{l}10^{3}- \\
<10^{4}\end{array}$ & 6 & 12 & 4 & 8 & 9 & 18 & 4 & 8 \\
\hline Total & 50 & 100 & 50 & 100 & 50 & 100 & 50 & 100 \\
\hline
\end{tabular}

$<3 *$ means negative results

Table 3: Incidence of E. coli recovered from the examined samples using MPN/ml.

\begin{tabular}{|c|c|c|}
\hline \multirow{2}{*}{ Egg samples } & \multicolumn{2}{|c|}{ Positive samples } \\
\cline { 2 - 3 } & No./50 & $\%$ \\
\hline Farm hens' egg shells & 3 & 6 \\
\hline Farm hens' egg contents & 4 & 8 \\
\hline Baladi hens' egg shells & 6 & 12 \\
\hline Baladi hens' egg contents & 3 & 6 \\
\hline
\end{tabular}

Table 4: Frequency distribution of the examined samples of shell and content based on their E.coli count (MPN/ml).

\begin{tabular}{|c|c|c|c|c|c|c|c|c|}
\hline \multirow[b]{3}{*}{$\begin{array}{c}\text { Coun } \\
t\end{array}$} & \multicolumn{4}{|c|}{ Farms eggs samples (No./50) } & \multicolumn{4}{|c|}{ Baladi eggs samples (No./50) } \\
\hline & \multicolumn{2}{|c|}{ Shells } & \multicolumn{2}{|c|}{ Contents } & \multicolumn{2}{|c|}{ Shells } & \multicolumn{2}{|c|}{ Contents } \\
\hline & $\begin{array}{l}\text { No. } \\
3\end{array}$ & $\%$ & $\begin{array}{l}\text { No./ } \\
4\end{array}$ & $\%$ & $\begin{array}{l}\text { No./ } \\
6\end{array}$ & $\%$ & $\begin{array}{l}\text { No.I } \\
3\end{array}$ & $\%$ \\
\hline$<3 *$ & 47 & 94 & 46 & 92 & 44 & 88 & 47 & 94 \\
\hline $\begin{array}{c}3- \\
<10\end{array}$ & 1 & 2 & 0 & 0 & 2 & 4 & 2 & 4 \\
\hline $\begin{array}{c}10- \\
<\mathbf{1 0}^{2} \\
\end{array}$ & 1 & 2 & 0 & 0 & 1 & 2 & 0 & 0 \\
\hline $\begin{array}{c}10^{2}- \\
< \\
10^{3} \\
\end{array}$ & 1 & 2 & 0 & 0 & 1 & 2 & 0 & 0 \\
\hline $\begin{array}{l}10^{3}- \\
<10^{4} \\
\end{array}$ & 0 & 0 & 4 & 8 & 2 & 4 & 1 & 2 \\
\hline Total & 50 & $\begin{array}{c}10 \\
0 \\
\end{array}$ & 50 & $\begin{array}{c}10 \\
0 \\
\end{array}$ & 50 & $\begin{array}{c}10 \\
0 \\
\end{array}$ & 50 & $\begin{array}{c}10 \\
0 \\
\end{array}$ \\
\hline
\end{tabular}

$<3 *$ means negative results

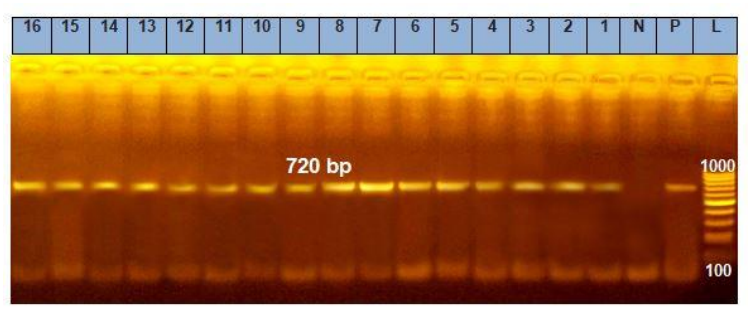

Figure 1. Agarose gel electrophoresis of PCR for phoA gene $(720 \mathrm{bp})$ of Escherichia coli isolated from the examined farm hens' egg and baladi hens' egg samples.

Lane L: 100 bp ladder as molecular size DNA marker Lane P: Control positive Escherichia coli for phoA gene Lane N: Control negative

Lane 1 - 16: positive Escherichia coli for phoA gene Lane 1 - 3: positive Baladi hens' egg contents

Lane 4 - 9: positive Baladi hens' eggshells

Lane 10 - 13: positive Farm hens' egg contents

Lane 14 - 16: positive Farm hens' eggshells

\section{Discussion}

Concerned to the incidence of farm egg shells the obtained results in Table 1 revealed that the incidence of coliforms was $62 \%$ and farm hens' egg contents incidence was $56 \%$, on the other side coliforms in baladi hens' eggs were $54 \%$ and $32 \%$ in shells and contents, respectively. Regarding the Fecal coliforms incidence was the same as Coliforms. The excessive counts of coliform in farm eggs may be related to unhygienic conditions in poultry farms. 
The result of coliform incidence was higher than results obtained by El-Prince (1988) (50\%) in winter, EL-Leboudy and EL-Mossalami (2006)(33.3\%), Refaat (2009) (37.1\%), El-Leboudy et al. (2011)(30\%) and El-Kholy et al. (2014) (47.06\%), and lower than that of Ahmed et al. (1985)(64\%) and El-Prince (1988)in (70\%) in summer, while in case of farm hens' egg contents the result was higher than that of ElPrince (1988) (10\%) and El-Kholy et al. (2014) (47.06\%), while Sadek et al. (2016) couldn't detect Coliforms in egg contents.

Regarding the incidence of coliforms in baladi hens' eggs shells, it was higher than the results detected by Refaat (2009) (51.4\%) and lower than that of ElLeboudy and El-Mossalami (2006) (69.3\%) and Sadek et al. (2016) (86.7\%). Concerning results in baladi hens' eggs content, the incidences were higher than the obtained by Sadek et al. (2016) and lower than that of El-Leboudy and El-Mossalami (2006) (58.66\%) while, Refaat (2009) couldn't find coliforms organisms in baladi hens' eggs content.

The incidence of fecal coliforms in farms hens' eggs shells was higher than that estimated by Refaat (2009); El-Kholy et al. (2014), Sadek et al. (2016) and ELGendi et al., (2019). While incidence in farms hens' eggs contents was higher than that isolated by ElKholy et al., (2014) (20.59\%) and EL-Gendi et al., (2019) (12.5\%). Meanwhile, Sadek et al., (2016) couldn't detect fecal coliform in farms hens' eggs contents.

In baladi hens' eggs shell, lower incidence of $22.9 \%$ was obtained by Refaat (2009) and $30 \%$ by EL-Gendi et al., (2019) and higher incidence of $73.3 \%$ was obtained by Sadek et al. (2016). While, the incidences in baladi hens' eggs contents were higher than 10 and $17.5 \%$ which was estimated by Sadek et al. (2016) and EL-Gendi et al. (2019), respectively.

The recorded results in Table 2 revealed that the highest frequency distribution of positive samples of Coliforms and fecal coliform of farm hens' eggshell was $22 \%$ and laid in the range of $3-<10 \mathrm{MPN} / \mathrm{ml}$ and the lowest was $8 \%$ and laid in the range $10^{\wedge} 2-<10^{\wedge} 3$ $\mathrm{MPN} / \mathrm{ml}$. like this the highest frequency distribution of farm hens' egg content was $18 \%$ and laid in the range of $3-<10 \mathrm{MPN} / \mathrm{ml}$ and the lowest was $8 \%$ and laid in the range $10^{\wedge} 3-<10^{\wedge} 4 \mathrm{MPN} / \mathrm{ml}$. On the other side, the highest frequency distribution of baladi hens' eggshell was $18 \%$ and laid in the range of $3-<10 \mathrm{MPN} / \mathrm{ml}$ and $10^{\wedge} 3-<10^{\wedge} 4 \mathrm{MPN} / \mathrm{ml}$ and the lowest was $4 \%$ and laid in the range $10^{\wedge} 2-<10^{\wedge} 3 \mathrm{MPN} / \mathrm{ml}$, as for the highest frequency distribution of baladi hens' egg content was $16 \%$ and laid in the range $10^{\wedge} 2-<10^{\wedge} 3$ $\mathrm{MPN} / \mathrm{ml}$ and the lowest was $2 \%$ and laid in the range $10-<10^{\wedge} 2$.

Escherichia coli population can be used as a measure of quality and sanitary processing conditions (Kornacki and Johnson, 2001). The biochemical identification revealed 16 isolates of Escherichia coli which was confirmed by the molecular identification by the conventional polymerase chain reaction (Photo 1). The E. coli isolates incidences were $6 \%$ of farm eggshell and $8 \%$ of farm egg content, while were 12 and $6 \%$ of Baladi eggshell and content, respectively. Table3.

Saitanu et al. (1994) isolated E. coli from eggshells and contents with rates of $3.5 \%$ and $1.2 \%$, respectively. Adesiyun et al. (2005) obtained 28.3\% isolation rate from eggshells and $(3.8 \%)$ from egg content. Mahdavi et al. (2012) detected E.coli from farms hens' eggs shell in incidence $6.1 \%$ while, $4 \%$ was found by Al-Ashmawy (2013). In contrast, higher incidences of 48, 48.89, 28.3, 14.71, 27.5 and $26.67 \%$ were reported by Ahmed et al. (1985); Bastawrows et al. (1997); Adesiyun et al. (2005); El-Kholy et al. (2014); Ibrahim et al. (2014); Fardows and Shamsuzzaman (2015), respectively. Meanwhile, Sadek et al., (2016) was isolated E. coli in $6.7 \%$ of farms hens' eggs shell.

Incidences of E. coli in Poultry farm egg contents were 11.76 and $30 \%$ which were detected by EL-Kholy et al., (2014) and Awny et al, (2018) respectively. Sadek et al., (2016) couldn't isolate E. coli and this result coincided with Refaat (2009), Al-Ashmawy (2013); El-Malt (2015) as the authors failed to isolate E. coli from farms hens' eggs content.

For baladi hens' eggs shell, the incidences of E. coli were isolated by percentage 32, 44 and $53.3 \%$ which were revealed by Al-Ashmawy (2013); Ibrahim et al. (2014) and Sadek et al. (2016), respectively. While, in the case of baladi hens' eggs content, the incidences of 23, 19 and 6.7\% were found by Al-Ashmawy (2013); Ibrahim et al. (2014), and Sadek et al. (2016), respectively. While Awny et al. (2018) was failed to detect E. coli.

The summarized results of Table. 4 indicated that the frequency distribution of E. coli in farm eggshell was laid in the range $3-<10,10-<10^{\wedge} 2$ and $10^{\wedge} 2-<10^{\wedge} 3$ 
$\mathrm{MPN} / \mathrm{ml}$ in equal percentage. Regarding the frequency distribution in farm egg content, it was $8 \%$ and all laid in the range $10^{\wedge} 3-<10^{\wedge} 4 \mathrm{MPN} / \mathrm{ml}$. On the other hand, the highest frequency distribution in baladi eggshell it was $4 \%$, which laid in the range $3-<10$ and $10^{\wedge} 3$ $<10^{\wedge} 4 \mathrm{MPN} / \mathrm{ml}$, while in baladi egg content the frequency was $2 \%$ in the range $3-<10 \mathrm{MPN} / \mathrm{ml}$ and $4 \%$ in the range $3-<10 \mathrm{MPN} / \mathrm{ml}$.

From the obtained results it is apparent that the count of E. coli isolated from both eggshells and egg contents, this might be attributed to the fact that E. coli are normal inhabitants of intestinal tracts of birds (Singleton and Sainsburg, 1981). They have also been known to contaminate the surface of egg, while the mechanical process can spread the bacteria through the eggs. Contaminations with the pathogen, while, in the field occur through improperly decomposed manure and poor hygienic practice of farmworkers. E. coli can bring about urinary tracts infections, pneumonia meningitis and peritonitis in humans (Schoeni and Doyle, 1994). This agrees with (USDA) 2011, which stated that microorganisms can be found both on the outside and inside of egg. This may be due to the fact that the egg and the feces share the same environment within and outside the laying bird. Feces known to be highly contaminated with microbes could contaminate the egg as it passes through the cloaca to be laid. Fecal contaminants on the shell of freshly laid eggs could also gain access into the eggs through the pores of the egg. (Ansah et al.,2009) reported that as eggs stay longer outside after lay, the natural barrier against microorganisms on the shell breaks down, thus reducing the eggs ability to resist the penetration of microorganisms into the content through the shell.

\section{Conclusion}

Because of the increasing consumption of eggs and their products, it is necessary to investigate egg contamination. we can recommend that strict hygienic measures to safeguard eggs from being deteriorated should be adopted in the farms and during handling and processing of eggs and raising public awareness to the importance of proper thermal processing and cooking of the egg.

\section{Conflict of interest}

The authors declare that they have no competing interest.

\section{References}

Adesiyun, A.; Offiah, N.; Seepersadsingh, N.; Rodrigo, S.; Lash-ley, V. and Musai, L. (2005): Microbial health risk posed by table eggs in Trinidad. Epidemiol Infect., 133: 1049-1056.

Ahmed, A-H.A.; Moustafa, K.M.; Aboul-Khier, F. and El-Bassiony, T.A. (1985): Bacterial contamination of eggshells. Assiut Vet. Med. J., 14 (27): $123-127$

Al-Ashmawy, Maha, A.M. (2013): Prevalence of Enterobacteriaceae in table eggs with particular reference to enterovirulent Escherichia coli strains. Int. J. Poultry Sci., 12 (7): 430-435.

Ansah, T., Dzoagbe, G.S.K., Teye, G.A., Adday, S. and Danquah, J.K. (2009) Microbial quality of table eggs sold on selected markets in the Tamale municipality in the Northern Region of Ghana. Livest. Res. Rural Dev., 21: 128.

A.O.A.C (Association of Official Analytical Chemists) (1980): Official methods of analysis. $15^{\wedge}$ th ed. Benjamin Franklin Station, Washington.

A.P.H.A. (American Public Health Association) (1992): standard method for examination of dairy Products $16^{\wedge}$ th ed. American Public Health Association. Washington D.C

Awny, C., Amer A.A. and Abo El-Makarem H. S. (2018): Microbial Hazards associated with consumption of table eggs. Alexandria J.Vet. Sci., 58: 139-146.

Bastawrows, A.F.; Khalil, Nawal, G.; Seedek, S.R. and Aly, Seham, M. (1997): Bacteriological studies on Enterobacteriaceae isolated from table eggs in Assiut. Assiut Vet. Med. J., 36 (72): 203-213.

Board, R.G. and Fuller, R. (1994): Microbiology of avian egg. 1st ed. Chapman and Hall p. 112- 128.

EL-Gendi, M. and Amin, M. (2019): Shiga toxigenic Escherichia coli isolated from table egg. Animal Health Research Journal, 7(1): 48-58.

El-Kholy, A. M.; Hassan, G. M. and Dalia, M.A. (2014): Microbiological Quality Of Poultry Farm Table Eggs In Beni-Suef city, Egypt. Assuit Vet. Med. J., 60: 142 . 
Ellen, H.H.; Bottcher, R.W.; Von Wachebfelt, E. and Takai, H. (2000): Dust levels and control methods in poultry houses. J. Agri. Safety Health, 6: 275-282.

EL-Leboudy; Ahlam, A. and EL-Mossalami, Hanna, A. (2006): Microbiological evaluation of table eggs with special reference to enteric pathogens in Alex. Governorate. Egypt. J. Vet. Med. Assoc., 66 (1): 141 153.

El-Leboudy, Ahlam, A.; El-Shenawy, N. and ElDayash, M. (2011): Criteria for evaluation of egg and egg products. Alexandria J. Vet. Sci., 34 (1): 77 88.

El-Malt, Laila, M. (2015): Assessment of the microbial quality and aflatoxins content in poultry farms eggs sold in Qena city- upper Egypt. Assiut Vet. Med. J., 61 (145): 144-151.

El-Prince, Enas, M. (1988): microbiological quality of hen's eggs. M.V.Sc. Thesis Fac. Vet. Med., Assiut Univ., Egypt.

Fardows, J. and Shamsuzzaman, S.M. (2015): A search for identifying aerobic bacteria by culture and multiplex PCR in market eggs causing gastroenteritis and enteric fever in Bangladesh. Annals Clin. Med. Microbiol., 1(1): 1001-107.

Hu, Q.; Tu, J.; Han, X.; Zhu, Y.; Ding, C. and Yu, S. (2011): Development of multiplex PCR assay for rapid detection of Riemerella anatipestifer, Escherichia coli, and Salmonella enterica simultaneously from ducks. Journal of Microbiological Methods 87 : 64-69.

Ibrahim, Jehan, I.; Mansour, Dali, H. and AbdelRahman, H.A. (2014): Prevalence and inhibition of microbial load on chicken eggs with special references to egg quality and hatchability. Am. J. Animal Vet. Sci., 9 (4): 294-302.

Kornacki, J. and Johnson, J. (2001): Enterobacteriacae, coliforms and Escherichia coli as quality and safety indicators. In F.P. Downes and K Ito (Eds.), Compendium methods microbial. exam. food.. Washington, pp.69-80.

MacFaddin, J.F. (2000): Biochemical test for identification medical bacteria. Warery Press Inc, Baltimore, Md.21202 USA.

Mahdavi, M.; Jalali, M.; Safaei, H. and Shamloo, E. (2012): Microbial quality and prevalence of
Salmonella and Listeria in eggs. Int. J. Envi. Health Eng., 1 (6): 16-20.

Mayes, F.J. and Takeballi, M.A. (1983): Microbial contamination of the hen's egg. A review. J. Food Port., 46: 1092-1098.

Ministry of Agriculture, Fisheries and Food (MAFF, UK) (2009): The Egg Quality Guide. Department for Environment Food and Rural Affairs (DEFRA), http://archive.defra.gov.uk/

foodfarm/food/industry/sectors/eggspoultry/eggs.htm

Musgrove, M.T.; Northcutt, J.K.; Jones, D.R.; Cox, N.A. and Harrison, M.A.(2008): Enterobacteriaceae and related organisms isolated from shell eggs collected during commercial processing. J. Poult. Sci., 87(6):1211-1218.

Moats, W.A. (1979): The effect of washing eggs under commercial conditions on bacterial load on egg shells. Poult. Sci., 58: 1228- 1233.

Queipo-Ortun, M.I.; Colmenero, J.D.D.; Macias, M.; Bravo, M.J. and Morata, P. (2008): Preparation of bacterial DNA template by boiling and effect of immunoglobulin $\mathrm{G}$ as an inhibitor in real-time PCR for serum samples from patients with brucellosis. Clinical and Vaccine Immunology, 15: 293-296.

Refaat, B.M. (2009): Microbiological evaluation of commercial hens and ducks eggs in Assiut governorate. M.V.Sc. Thesis, Fac. Vet. Med., Assiut Univ., Egypt.

Roberts, J.R. (2010): Egg quality and food safety. 18th Annual ASAIM SE Asian Feed Technol. and Nut. Workshop Australia. May 24-27, Le Meridien Siem Reap. Cambodia

Sadek, O. A.; Hussein, M. F. and El Berbawy, S. M. (2016): Microbiological Status of Farms And Baladi Hens' Eggs. Assiut Vet. Med. J., 62: 58 - 68.

Saitanu, K.; Koowatananukul, C.; Jerngklinchan, J. and Sasipreeyajan, J. (1994): Detection of Salmonellae in hen eggs in Thailand. Southeast Asian J Trop Med Public Health; 25(2): 324-7.

Sambrook, J.; Fritscgh, E.F. and Mentiates (1989): Molecular cloning. A laboratory manual. Vol. 1, Cold spring Harbor Laboratory press, New York. 
Schoeni, J.L. and Doyle, M.P. (1994): Variable colonization of chickens per orally inoculated with Escherichia coli O157:H7 and subsequent contamination of eggs. Appl. Environ. Microbiol., 60: 2958-2962.

Singleton, P. and Sainsburg, D. (1981): Dictionary of microbiology. International edition. John Willey and Sons Limited Publication, New York. Pp 425-426.

Singleton P (1999). Bacteria in Biology, Biotechnology and Medicine (5th Ed.), Wiley; pp. 444-454.

Speck, M.L. (1976): Compendium of Methods for Microbiological Examination of Foods. American Public Health Association. Washington D.C.

Todar, K. (2007): Pathogenic E. coli. Online Textbook of Bacteriology. University of Wisconsin-Madison Department of Bacteriology.

United State Department of Agriculture, Food Safety and Inspection Services, (USDA). (2011) Shell eggs from farm to table. Available from: http://www.fsis.usda.gov. Retrieved on 12-04-2014.

WHO (2002): World Health organization. Department of communicable diseases surveillance and response. 